\title{
Biotic potential of mucus extracts of giant mudskipper Periophthalmodon schlosseri (Pallas, 1770) from Pichavaram, southeast coast of India
}

\author{
Gopalan Mahadevan*, Kannan Mohan, Jothiprakasam Vinoth and Velayudham Ravi
}

\begin{abstract}
Background: The epidermal mucus of fish contains various bioactive compounds, which play a crucial role in the animal defense mechanisms. However, the mucus from giant mudskipper is not well characterized for its biochemical and pharmacological effects. This study for the first time analyzed the mucus extracts of this species for antimicrobial (against human pathogen) and hemolytic activities. Fourier-transform infrared spectrum analysis (FT-IR) and SDS-PAGE of mucus extracts were also carried out.

Results: The protein content in Periophthalmodon schlosseri (Gobiidae: Oxudercine) mucus extracts was $0.66 \pm 0.04$ $\mathrm{mg} / \mathrm{ml}$. The mucus extracts of $P$. schlosseri showed antibacterial activity against all eight human pathogenic bacteria and four fungal strains tested in this study. The hemolytic activities against chicken and human blood cells were observed with maximum activity for dichloromethane extracts. The FT-IR spectrum of mucus extract of $P$. schlosseri showed the presence of functional groups, evident protein bands of various molecular weights ranging from $14 \mathrm{kDa}$ to $97 \mathrm{kDa}$.

Conclusion: The obtained results suggested that the mucus of this species has proteinaceous compounds responsible for antimicrobial and hemolytic activities.
\end{abstract}

Keywords: Periophthalmodon schlosseri, Antimicrobial, Hemolytic, SDS-PAGE, FT-IR

\section{Background}

Fish and fish products are rich in high valuable proteins, minerals, enzymes, and pigments (Hellio, Pons, Beaupoil, Bourgougnon, \& Le Gal, 2002). Fish lives in an environment which is a source of microorganisms that can be potentially pathogenic. Fish can still preserve a fit and vigorous system under normal condition. Skin or mucus of fish contains biologically active compounds with a potential against human pathogens. The mucus is composed of chemical substances secreted from the epithelial cells covering the epidermal surface (Rakers et al., 2013). Mucus contains mucin-like substances which have an antibiotic potential (Ingram, 1980) that reduces the

\footnotetext{
* Correspondence: marinemahadevan@gmail.com

CAS in Marine Biology, Faculty of Marine Sciences, Annamalai University, Parangipettai, Tamil Nadu 608 502, India
}

adhesive potential of bacteria present in mucus and is believed to be a key virulence factor (Ellis, 2001).

The mucus substances produced by fish act as a lubricant (Ellis, 1999; Shephard, 1994). The mucus layer acts as a barrier between fish and its aquatic environment and is presumed to be involved in a number of certain functions including immunological, respiratory, osmosis, locomotory, reproductive, signaling, foraging, and nesting (Uribe, Folch, Enriquez, \& Moran, 2011). Proteinaceous slimy discharge of the fishes contains antibiotic peptides, as their first developed basics of innate immunity defense line and they act as a natural resistance of animals against microorganisms (Balasubramanian, Baby Rani, Prakash, \& Prakash, 2012; Manivasagan, Annamalai, Ashokkumar, \& Sampathkumar, 2009). The aqueous extracted mucus of fishes demonstrated the presence of various innate antimicrobial agents such as lysozyme, cathepsin B, and 
trypsin-like proteases (Caruso et al., 2010; Caruso et al., 2014; Subramanian, Mackinnon, \& Ross, 2007), and it may be a source of novel antimicrobial agents for fish and human health-related applications.

The antimicrobial property of epidermal mucus in fishes is reported by various researchers from throughout the world: common carp (Cyprinus carpio) by Lemaitre et al. (1996); hagfish (Myxine glutinosa) by Subramanian, Rose, and Mackinnon (2008); catfish (Arius maculatus) by Manivasagan et al. (2009); bluespotted mudskipper (Boleophthalmus boddarti) by Ravi, Kesavan, Sandhya, and Rajagopal (2010); and eel fish (Anguilla anguilla) Caruso et al. (2010 and 2014).

Mudskippers (Gobiidae: Oxudercine) inhabits the intertidal mudflats and mangrove areas where they live under varying environmental conditions (tide, wind, temperature, $\mathrm{pH}$, and hypoxic soils) and they have certain various physiological adaptations for their survival (Graham \& Lee, 2004). Mudskippers can secrete slime to protect the skin from scratch and dehydration. Discovery of novel drugs is the most significant biomedical current research and is due to untreatable diseases as well as increased resistance to current therapeutic treatments of many bacterial pathogens. In biosynthetic biomedical exploration, the marine natural products (MNPs) such as new antibiotics are still a high priority in biosynthetic biomedical exploration, and therefore, in the present study, the mucus extracts of $P$. schlosseri were screened to evaluate their antimicrobial and hemolytic properties.

\section{Methods}

\section{Sample collection and preparation of mucus extract}

Specimens of the giant mudskipper Periophthalmodon schlosseri were freshly collected from Pichavaram, southeast coast of India (lat. $11^{\circ} 26^{\prime} \mathrm{N}$, long.79 $48^{\prime} \mathrm{E}$ ). Fishes were anesthetized and euthanized with a lethal dose of MS-222 (tricaine methanesulfonate, $0.1 \mathrm{~g} \mathrm{l}^{-1}$, Sigma-Aldrich). Samples of skin mucus were collected from fish by gently scraping with a sterile spatula from the dorsal surface of the body; the ventral side of the body was not considered for the same in order to avoid intestinal and sperm contamination. It was further stored in sterile Eppendorf microcentrifuge tubes and mixed with an equal amount of sterilized physiological saline $(0.85 \% \mathrm{NaCl})$. Precipitates present in the suspension were removed by centrifugation at $6000 \mathrm{rpm}$, and the supernatant was collected and stored at $-20^{\circ} \mathrm{C}$ until analysis. The mucous portion was lyophilized, and its protein content was estimated according to Lowry, Rosenbrogh, Farr, and Randall (1951) using bovine serum albumin as a standard.

The lyophilized mucus was suspended in phosphatebuffered saline buffered ( $\mathrm{pH} 7.4)$ at $1 \mathrm{mg} / \mathrm{ml}$ concentration to prepare the aqueous extract $\mathrm{A}$. For the ethanolic extract preparation, the lyophilized sample $(1 \mathrm{mg} / \mathrm{ml})$ was suspended in absolute ethanol and centrifuged at 12,000 rpm for $45 \mathrm{~min}$. The pellet was collected and washed with absolute ethanol for three more times, and the supernatant was discarded. The ethanol extracts were collected, suspended, and washed with distilled water to a final volume of $50 \mathrm{ml}$, and this was extracted with dichloromethane $\left(\mathrm{CH}_{2} \mathrm{Cl}_{2} ; 4{ }^{\circ} \mathrm{C}, 50 \mathrm{ml}\right.$; extract $\left.\mathrm{B}\right)$. The dichloromethane phase was collected and lyophilized; the finally dried extracts were dissolved in water and in 5\% DMSO, respectively (Vennila et al., 2011).

\section{Antimicrobial activity}

Antibacterial activity of mucus extracts was determined by following Subramanian et al. (2007). The bacterial pathogens selected for the present study were Proteus mirabilis, Pseudomonas aeruginosa, Escherichia coli, Staphylococcus aureus, Salmonella typhi, Vibrio cholerae, Bacillus anthracis, and Klebsiella pneumoniae. The fungal pathogens Candida albicans, Aspergillus flavus, Mucor sp., and Trichoderma longibriachtin were acquired from the Medical Microbiology Laboratory of Annamalai University. All eight species of bacterial strains were subcultured in Brain Heart Infusion Agar, and the fungal strains were maintained in Sabouraud Dextrose Agar. Antimicrobial activity of mucus extracts from $P$. schlosseri was determined by agar disc diffusion method against a $0.5 \mathrm{McFarland}$ standard concentration of eight different bacterial strains and four fungal pathogens.

Sterile discs of Whatmann No. 1 filter paper were soaked with $30 \mu \mathrm{g} / \mathrm{ml}$ of each extract. The discs were placed on the surface of Mueller Hinton agar plates previously streaked with a broth culture of each pathogenic strain. The plates were incubated at $37^{\circ} \mathrm{C}$ for pathogenic bacteria and $28^{\circ} \mathrm{C}$ for pathogenic fungus. After the incubation, the diameter of the zone of incubation was measured using a caliper. Discs soaked with erythromycin $(20 \mu \mathrm{g} / \mathrm{disc})$ and nystatin (100 units/disc) were used as positive control for bacteria and fungi, respectively.

\section{Minimum inhibitory concentration}

Minimum inhibitory concentration (MIC) was determined by serial dilution of the two extracts in four concentrations of $10,20,30,40$, and $50 \mu \mathrm{g} / \mathrm{ml}$. Bacteria $\left(2 \times 10^{8}\right)$ were grown in Mueller Hinton broth incubated at $37^{\circ} \mathrm{C}$ and fungi in Muller Hinton broth at $28^{\circ} \mathrm{C}$. MIC was determined as the lowest concentration necessary to inhibit the microbial growth. All assays were carried out in triplicate, using $2 \%$ DMSO as a negative control.

\section{Hemolytic activity}

\section{Preparation of erythrocytes suspension}

The mucus extracts were examined for the hemolytic activity against chicken and human erythrocytes. Fresh 
chicken and human blood were mixed with 2.7\% EDTA solution as anticoagulant and centrifuged at $5000 \mathrm{rpm}$ for $10 \mathrm{~min}$. Erythrocyte (3\%) suspensions were used for hemolytic activity analysis (Caruso et al., 2014).

\section{Microtitre plate assay}

Hemolytic activity assay was performed in 96-well sterile Laxbro microtiter plates. Twofold serial dilutions of the mucus extracts were carried out in $100 \mu \mathrm{l}$ of PBS $(5 \mathrm{mg} /$ $\mathrm{ml}$ ), $\mathrm{pH} 7.4$, and then, $100 \mu \mathrm{l}$ of $3 \%$ red blood cell (RBC) suspension was added to each well. One hundred microliter of distilled water and $100 \mu \mathrm{l}$ of PBS ( $\mathrm{pH} 7.4$ ) were added to the $3 \%$ RBC suspension for positive control and negative control, respectively. The plate was shaked in a gentle manner, and then, it was incubated for $2 \mathrm{~h}$ at room temperature. An evident red coloration in the wells was considered as a sign of positive hemolysis, while a pellet formation at the bottom of the wells was considered as a sign of a lack of hemolysis. The highest dilution of the extract resulting in a clear hemolysis was considered as the specific hemolytic titer.

\section{Fourier-transform infrared spectroscopic analysis}

The epidermal mucus extract A and B of giant mudskipper $P$. schlosseri were lyophilized to determine the functional group by using fourier-transform infrared (FT-IR) spectroscopy.

\section{Sodium dodecyl sulphate-polyacrylamide gel electrophoresis}

In order to estimate the molecular weight of the active components of the proteinaceous gel, Sodium dodecyl sulphate-polyacrylamide gel electrophoresis (SDS-PAGE) of the extracts was carried out in $10 \%$ polyacrylamide separating gels ( $P$. schlosseri mucus protein). The gel was run in a BioRad electrophoresis apparatus for $1.5-5.5 \mathrm{~h}$ at $30 \mathrm{~V}$ during initial voltage then followed by $150 \mathrm{~V}$ until $2 \mathrm{~mm}$ from the base of the gel. The obtained bands were observed after silver staining (Manivasagan et al., 2009).

\section{Results}

The total protein concentration in the crude mucus extract of P. schlosseri was found to be $0.66 \pm 0.04 \mathrm{mg} / \mathrm{ml}$.

\section{Antibacterial activity}

The mucus extracts of $P$. schlosseri showed antibacterial activity against all eight clinical bacterial strains (Table 1). The mucus extract A showed the highest inhibition zone against Ps. aeruginosa $(13 \mathrm{~mm})$, whereas the lowest was observed against $S$. aureus $(8 \mathrm{~mm})$. The mucus extract B showed the highest diameter of inhibition zone against S. typhi $(18 \mathrm{~mm})$. The lowest inhibition zone $(10 \mathrm{~mm})$ was observed against $B$. anthracis.
Table 1 Antibacterial activity of mucus extract against human pathogens

\begin{tabular}{|c|c|c|c|c|}
\hline \multirow{2}{*}{$\begin{array}{l}\text { S. } \\
\text { No. }\end{array}$} & \multirow[t]{2}{*}{ Name of the strains } & \multicolumn{3}{|c|}{ Zone of inhibition (mm) } \\
\hline & & Standard & $\begin{array}{l}\text { Aqueous } \\
\text { extract }\end{array}$ & $\begin{array}{l}\text { Organic } \\
\text { extract }\end{array}$ \\
\hline 1 & Proteus mirabilis & 22 & 10 & 12 \\
\hline 2 & $\begin{array}{l}\text { Pseudomonas } \\
\text { aeruginosa }\end{array}$ & 21 & 13 & 16 \\
\hline 3 & Escherichia coli & 19 & 11 & 15 \\
\hline 4 & Staphylococcus aureus & 17 & 08 & 12 \\
\hline 5 & Salmonella typhi & 20 & 11 & 18 \\
\hline 6 & Vibrio cholerae & 26 & 13 & 14 \\
\hline 7 & Klebsiella pneumoniae & 18 & 11 & 12 \\
\hline 8 & Bacillus anthracis & 17 & 09 & 10 \\
\hline
\end{tabular}

\section{Antifungal activity}

The mucus extract of $P$. schlosseri showed antifungal activity against all four fungal strains tested (Table 2). The mucus extract A showed a maximum zone of inhibition $(11 \mathrm{~mm})$ against $C$. albicans and T. longibriachtin. The minimum zone of inhibition $(9 \mathrm{~mm})$ was observed against $A$. flavus. The mucus extract $\mathrm{B}$ showed higher zone of inhibition $(16 \mathrm{~mm})$ against Mucor sp., while the lower zone of inhibition $(13 \mathrm{~mm})$ was observed against A. flavus.

\section{Minimum inhibitory concentration}

The MIC values ranged between 3.0 and $25 \mathrm{mg} / \mathrm{ml}$ for the different bacterial pathogens; for the fungal pathogens, values ranged between 0.1 and $0.7 \mathrm{mg} / \mathrm{ml}$. For both extracts (aqueous and dichloromethane phase), the lowest MIC value of bacterial pathogens ( 3 and $1 \mathrm{mg} / \mathrm{ml}$ ) was found against Ps. aeruginosa and K. pneumonia, respectively. Regarding the fungal pathogens, both extracts showed a MIC of $0.7 \mathrm{mg} / \mathrm{ml}$ against Mucor sp. (Table 3).

\section{Hemolytic activity}

The mucus extracts A and B showed an hemolytic activity of 73.73 and $129.55 \mathrm{HT} / \mathrm{mg}$ against chicken

Table 2 Antifungal activity of mucus extract against the human pathogens

\begin{tabular}{lllll}
\hline S. & Name of the strains & \multicolumn{2}{l}{ Zone of inhibition $(\mathrm{mm})$} \\
\cline { 3 - 5 } & & Standard $\begin{array}{l}\text { Aqueous } \\
\text { extract }\end{array}$ & $\begin{array}{l}\text { Organic } \\
\text { extract }\end{array}$ \\
\hline 1 & Aspergillus flavus & 18 & 09 & 13 \\
2 & Mucor sp. & 22 & 10 & 16 \\
3 & Candida albicans & 19 & 11 & 15 \\
4 & $\begin{array}{l}\text { Trichoderma } \\
\text { longibriachtin }\end{array}$ & 16 & 11 & 14 \\
\hline
\end{tabular}


Table 3 Minimum inhibitory concentration of mucus extracts

\begin{tabular}{llll}
\hline Microorganisms & Pathogens & \multicolumn{2}{l}{ Mucus extracts $(\mathrm{mg} / \mathrm{ml})$} \\
\cline { 3 - 4 } & & $\begin{array}{l}\text { Aqueous } \\
\text { extract }\end{array}$ & $\begin{array}{l}\text { Organic } \\
\text { extract }\end{array}$ \\
\hline Bacteria & Proteus mirabilis & 20 & 25 \\
& $\begin{array}{l}\text { Pseudomonas } \\
\text { aeruginosa }\end{array}$ & 03 & 12 \\
& Escherichia coli & 06 & 25 \\
& Staphylococcus aureus & 12 & 12 \\
& Salmonella typhi & 06 & 12 \\
& Vibrio cholerae & 08 & 05 \\
& Klebsiella pneumoniae & 12 & 01 \\
& Bacillus anthracis & 12 & 12 \\
& A. flavus & 0.8 & 0.9 \\
& Mucor sp. & 0.7 & 0.7 \\
& C. albicans & 1.2 & 1.1 \\
& T. longibriachtin & 1.3 & 1.0 \\
\hline
\end{tabular}

erythrocytes and 43.47 and $73.73 \mathrm{HT} / \mathrm{mg}$ in $\mathrm{A}, \mathrm{B}, \mathrm{AB}$, and O group of human blood, respectively (Tables 4 and 5).

\section{FT-IR analysis}

The FT-IR analysis of mucus extract A of $P$. schlosseri revealed the presence of different functional groups (Fig. 1). The analysis gave a sharp peak at $3428 \mathrm{~cm}^{-1}$, which indicated the presence of $\mathrm{O}-\mathrm{H}$ bounds in the mucus extract, depicting the presence of alcohols. Another sharp peak obtained in the extract was related to alkanes, with $\mathrm{C}-\mathrm{H}$ bounds at $3026 \mathrm{~cm}^{-1}$. The absorption peak at $1685 \mathrm{~cm}^{-1}$ was assigned to $\mathrm{C}=\mathrm{O}$ bound vibration in carbonyl compounds. Moreover, the peak generated at $1438 \mathrm{~cm}^{-1}$ represented a $\mathrm{CH}_{2}$ bending. The peak for the $\mathrm{C}-\mathrm{O}$ stretch was at $1128 \mathrm{~cm}^{-1}$ and alkyl halide $\mathrm{C}-\mathrm{Cl}$ stretch at $572 \mathrm{~cm}^{-1}$.

The result of FT-IR analysis of mucus extract $\mathrm{B}$ gave a sharp peak at $3433 \mathrm{~cm}^{-1}$, which indicated the presence of $\mathrm{O}-\mathrm{H}$ bounds, a medium band at $3050 \mathrm{~cm}^{-1}$ for alkanes $\mathrm{C}-\mathrm{H}$ bounds (Fig. 2), while peaks obtained at $1670 \mathrm{~cm}^{-1}$ showed the presence of $\mathrm{C}=\mathrm{O}$ bounds related to carboxylic acids. Another peak at $1487 \mathrm{~cm}^{-1}$ represented a C- $\mathrm{H}_{2}$ bending, $\mathrm{C}-\mathrm{O}$ bounds at $1102 \mathrm{~cm}^{-1}$, whereas alkyl halide $\mathrm{C}-\mathrm{Cl}$ stretch at $615 \mathrm{~cm}^{-1}$.

Table 4 Hemolytic activity of mucus extracts in chicken blood

\begin{tabular}{llcll}
\hline S. & Sample & \multicolumn{3}{l}{ Source of blood_chicken blood } \\
\cline { 3 - 5 } & $\begin{array}{l}\text { Total hemolysis } \\
\text { (up to dilution) }\end{array}$ & $\begin{array}{l}\text { Hemolytic } \\
\text { unit (H/T) }\end{array}$ & $\begin{array}{l}\text { Specific hemolytic } \\
\text { activity }(\mathrm{HT} / \mathrm{mg})\end{array}$ \\
\hline 1 & $\begin{array}{l}\text { Aqueous } \\
\text { extract }\end{array}$ & 4 & 8 & 73.73 \\
2 & $\begin{array}{l}\text { Organic } \\
\text { extract }\end{array}$ & 5 & 16 & 129.55 \\
\hline
\end{tabular}

\section{Sodium dodecyl sulfate-polyacrylamide gel electrophoresis}

The SDS-PAGE analysis (Fig. 3) depicted the presence of evident protein bands of various molecular weights ranging from $14.3 \mathrm{kDa}$ to $97.4 \mathrm{kDa}$. The mucus extract A showed bands at 97.4, 66, 43, and $29 \mathrm{kDa}$ and the mucus extract B at $14.3,29$, and $43 \mathrm{kDa}$ which is similar to the used standard.

\section{Discussion}

The involvement of epidermal mucus enzymes such as lysozyme, cathepsin B, and proteases in the innate immune mechanism of fish has been studied previously (Aranishi, 1999; Yano, 1996). Presence of certain hydrolytic enzymes including lysozyme, AP, cathepsin B, and proteases has been studied from a number of fishes, but no information is available for the fish species examined in this study.

In this study, the protein content in the crude mucus extract of $P$. schlosseri was found and similar reports also have been made by previous researchers; Manivasagan et al. (2009) reported the mucus of $A$. maculates have $12.64 \mu \mathrm{g} / \mathrm{g}$ of protein content; Wei, Xavier, and Marimuthu (2010) also reported protein content in both crude and aqueous mucus extract of Channa striatus. Dhotre, Bansode, and Shembekar (2013) also characterized the biochemical composition of freshwater fishes, viz., Channa punctatus, Channa gachua, Cyprinus carpio, and A. dussmieri, and found similar results.

In the present study, the $P$. schlosseri organic mucus extract (extracted with the polar solvent ethanol and non-polar solvents DMSO) exhibited greater potent inhibitory activity against both bacterial and fungal pathogens than the aqueous mucus extract against human pathogens tested. Earlier, Subramanian et al. (2008) also reported low microbial growth inhibition in aqueous fish mucus extracts of a wider range of fish species including Arctic char (Salvelinus alpinus), brook trout (Salvelinus fontinalis), koi carp (Cyprinus carpio), striped bass (Morone saxatilis), haddock (Melanogrammus aeglefinus), and hagfish (Myxine glutinosa) could be due to the presence of low levels of enzymes. In contradiction, this strong inhibitory effect of aqueous mucus extract was reported from various eel fishes Anguilla linnaeus and Mastacembelus armatus (Bragadeeswaran \& Thangaraj, 2011; Uthayakumar, Ramasubramanian, Senthilkumar, Brindha, \& Harikrishnan, 2012). Hellio et al. (2002) reported that fish (Pollachius virens, Labrus bergylta, Scophthalmus rhombus, Platichthys flesus, and Solea solea) mucus extracted with ethanol and DMSO (organic extract) showed strong bactericidal activity against a broad range of pathogens. The results of the present study also indicated that the proteinaceous substances in the mucus 
Table 5 Haemolytic activity of the different mucus extracts in human blood

\begin{tabular}{|c|c|c|c|c|c|c|c|}
\hline \multirow{2}{*}{$\begin{array}{l}\text { S. } \\
\text { No }\end{array}$} & \multirow[t]{2}{*}{ Sample } & \multirow{2}{*}{$\begin{array}{l}\text { Total } \\
\text { hemolysis } \\
\text { (up to } \\
\text { dilution) }\end{array}$} & \multirow{2}{*}{$\begin{array}{l}\text { Hemolytic } \\
\text { unit }(H / T)\end{array}$} & \multicolumn{4}{|c|}{ Specific hemolytic activity (HT/mg)_human blood } \\
\hline & & & & A & $\mathrm{B}$ & $A B$ & $\mathrm{O}$ \\
\hline 1 & Aqueous extract & 4 & 8 & 41.0 & 36.1 & 43.47 & 43.47 \\
\hline 4 & Organic extract & 5 & 16 & ND & 29.0 & 73.73 & 73.73 \\
\hline
\end{tabular}

ND non-detectable

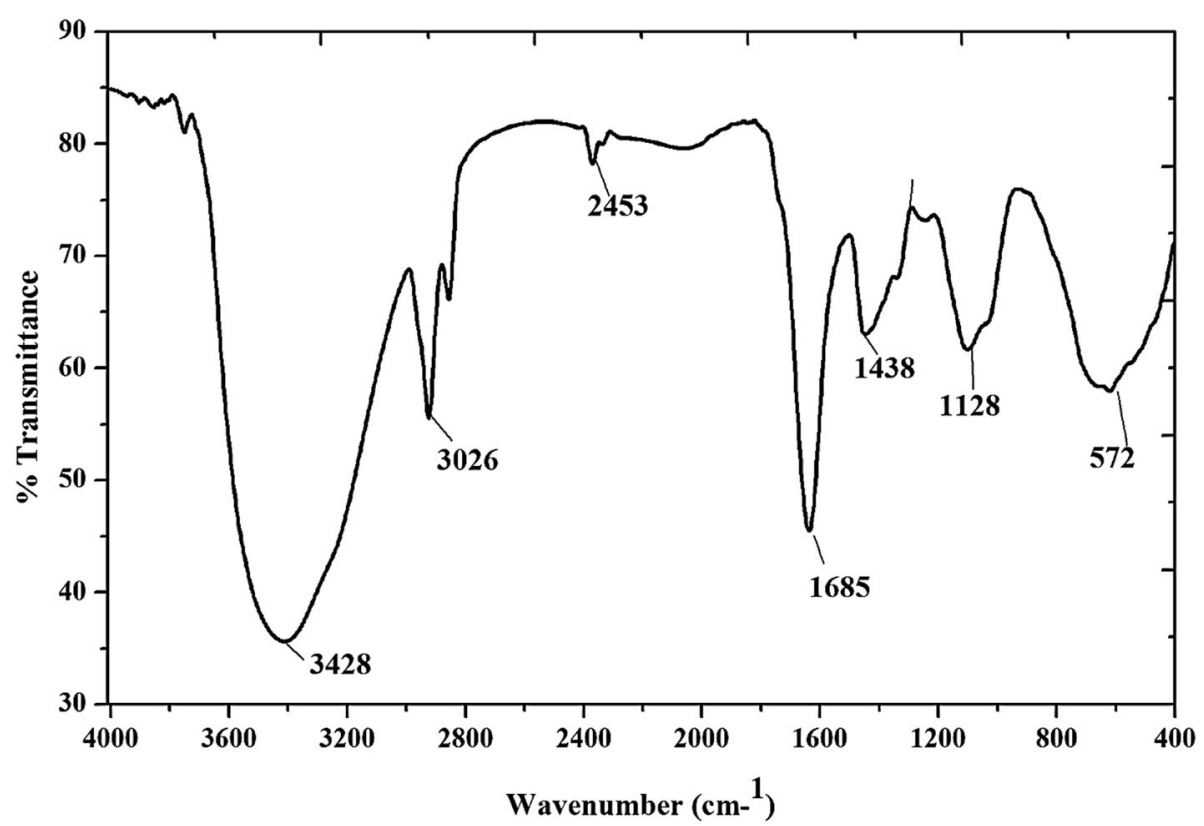

Fig. 1 Fourier-transform infrared spectrum analysis of Periophthalmodon schlosseri aqueous mucus extract

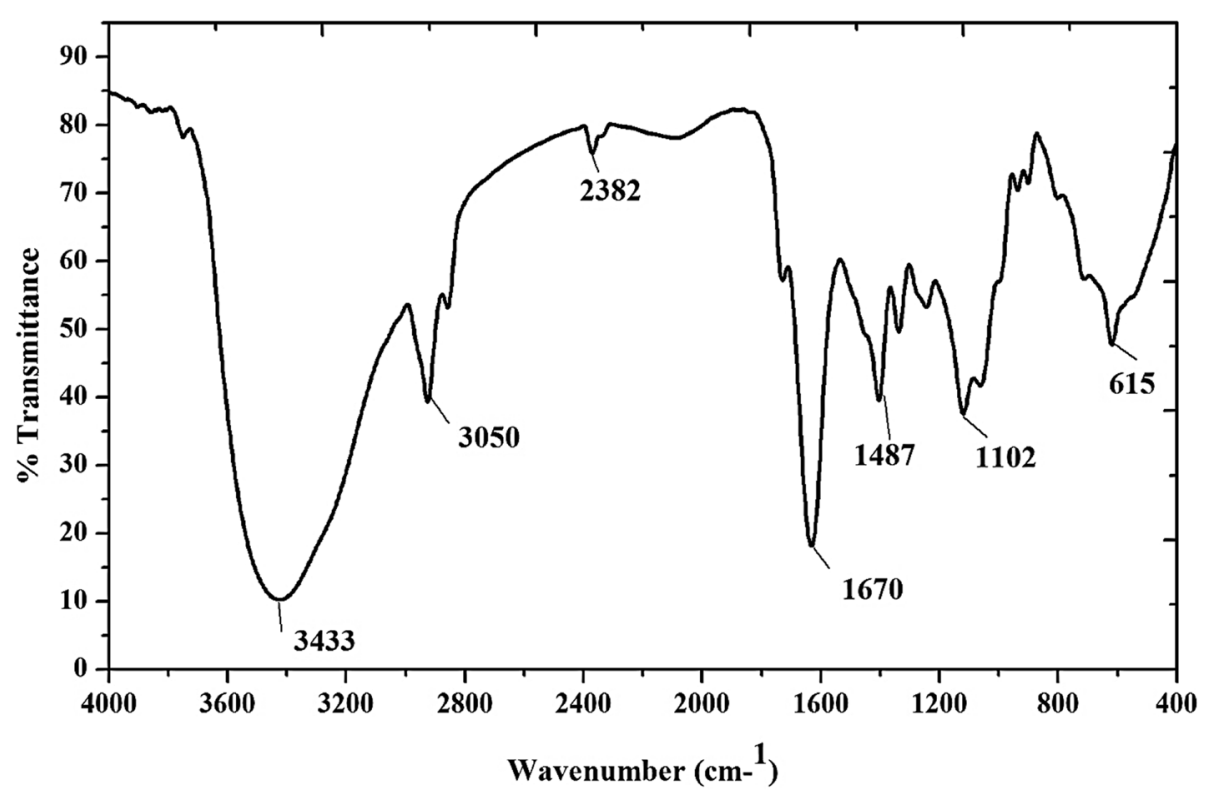

Fig. 2 Fourier-transform infrared spectrum analysis of Periophthalmodon schlosseri organic mucus extract 


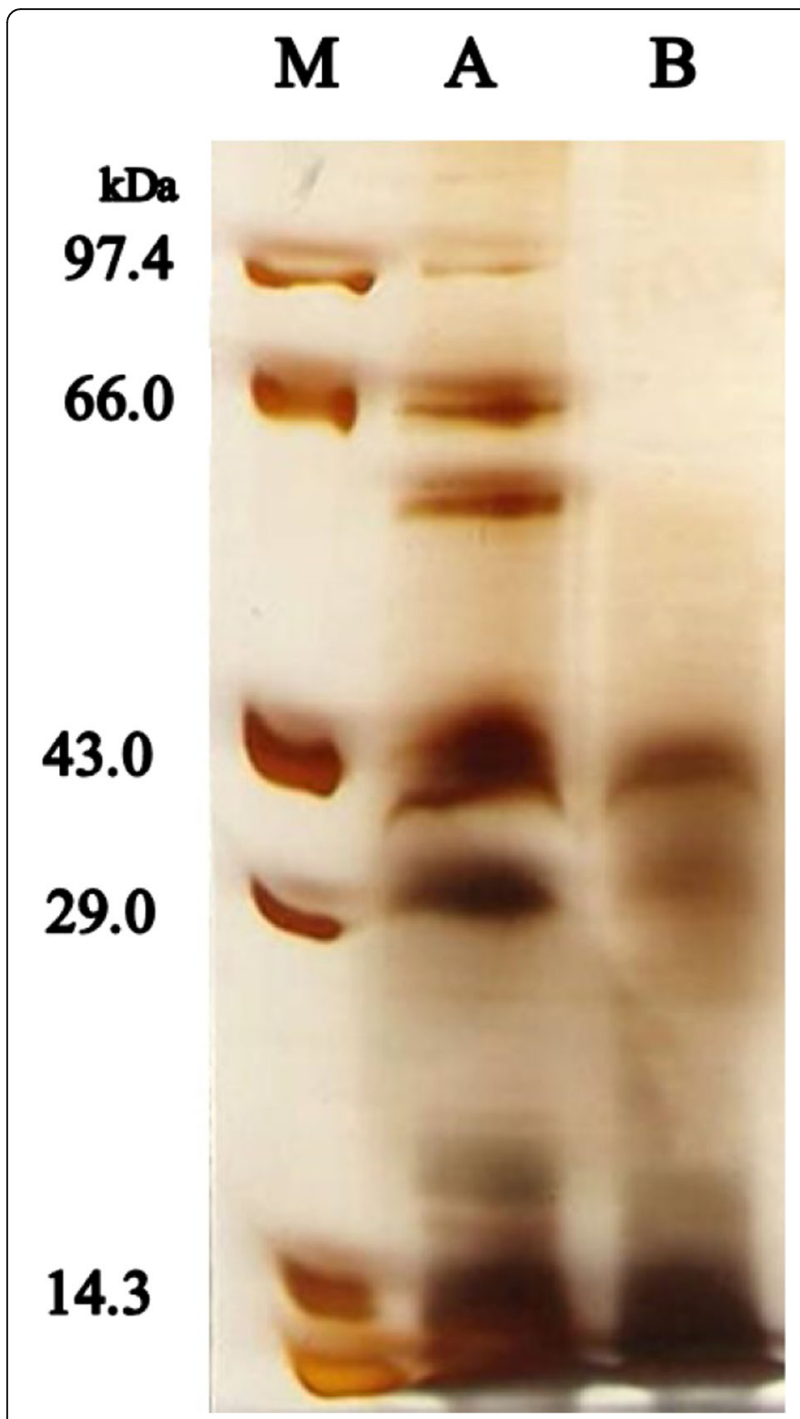

Fig. 3 SDS-PAGE analysis of Periophthalmodon schlosseri aqueous (A) and organic (B) mucus extract in comparison to marker (M)

of $P$. schlosseri, extracted using organic solvents, had most active antimicrobial components.

Further, the antimicrobial activity of epidermal mucus extracted with organic and aqueous solvents varies remarkably within and among the fish species (Subramanian et al., 2008). The variation in antimicrobial activities in the mucus of $P$. schlosseri is thought to be due to the diverse composition of the secreted mucus. The mucus-producing cells in epidermal and epithelial layer of fish had been reported to differ between fish species (Shephard, 1993) and therefore could influence the mucus composition.

The mucus of P. schlosseri contained protein derivatives which exhibited potent hemolytic activity when mixed with chicken and human blood. The mucus of P. schlosseri extracted using organic solvent (extract B) exhibited high level of hemolytic activity. Hellio et al. (2002) reported that lysozyme in the mucus has bacteriostatic properties and was ubiquitous in its distribution among living organisms. Bragadeeswaran, Priyadharshini, Prabhu, Raj, and Rani (2011) reported that the fish mucus of Cynoglossus arel and Arius caelatus has potential hemolytic activity. Similarly, Uthayakumar et al. (2012) also reported hemolytic activity (against sheep and cow blood cells) of mucus extracts of $M$. armatus.

The mucus of $P$. schlosseri extracted using organic solvent (extract B) showed low molecular mass protein bands $(14.3,29,43.0 \mathrm{kDa})$ was prominent. The more intense protein bands of molecular mass $14.3 \mathrm{kDa}$ were noticed in both mucus extracts. Rao et al. (2015) reported that the acidic extracts of Chrysichthys nigrodigitatus and Tilapia sp. showed more prominent bands in low molecular mass. Hence, this could be attributed that low molecular mass proteins of $P$. schlosseri mucus extracted using organic solvent could be a novel source of antimicrobial peptide. This study confirms that even the low concentration of organic extracts has high activity against both bacterial and fungal pathogens. The FT-IR analysis of the mucus of $P$. schlosseri showed wide spectral profile which confirms the presence of primary amine group, aromatic compound, halide group, aliphatic alkyl group, and polysaccharides.

\section{Conclusions}

There are many proteinaceous substances present in the fish mucus which exert strong resistance to invading pathogens. These findings prove that the mucus collected from the fish $P$. schlosseri shows strong antimicrobial and hemolytic potential. Further, purification of bioactive compounds is necessary in order to identify their chemical nature and to evaluate their potential as novel drugs.

\section{Abbreviations \\ AMPs: Antimicrobial peptides; BSA: Bovine serum albumin; \\ $\mathrm{CH}_{2} \mathrm{Cl}_{2}$ : Dichloromethane; DMSO: Dimethyl sulfoxide; \\ EDTA: Ethylenediaminetetraacetic Acid; FT-IR: Fourier-transform infrared spectroscopy; kDa: Kilodaltons; MIC: Minimum inhibitory concentration; MNPs: Marine natural products; PSA: Phosphate-buffered saline; RBC: Red blood cell; SDS-PAGE: Sodium dodecyl sulfate-polyacrylamide gel electrophoresis}

\section{Acknowledgements}

The authors would like to thanks the Director \& Dean, Faculty of Marine Sciences and authorities of Annamalai University for the facilities.

\section{Funding}

The authors are grateful to the Ministry of Human Resource \& Development (MHRD), New Delhi for the financial support.

Availability of data and materials

The data supporting the conclusions of this article is included within the article. The authors can be contacted for any additional supporting data required by the journal. 


\section{Authors' contributions}

GM participated in the design of this research work and performed the collection of samples. VR contributed in the analytical part. KM undertook the characterization studies. GM, KM, and JV wrote the manuscript. VR supervised the findings of this work. All authors discussed the result and contributed to the final manuscript. All authors read and approved the final manuscript.

\section{Ethics approval and consent to participate}

The authors declare that no animal was sacrificed for this study.

\section{Consent for publication}

Not applicable.

\section{Competing interests}

The authors declare that they have no competing interests.

\section{Publisher's Note}

Springer Nature remains neutral with regard to jurisdictional claims in published maps and institutional affiliations.

\section{Received: 17 August 2018 Accepted: 8 February 2019}

Published online: 20 February 2019

\section{References}

Aranishi, F. (1999). Possible role for cathepsins $L$ and B in bacteriolysis by Japanese eel skin. Fish and Shellfish Immunology, 9, 61-64. https://doi.org/10. 1006/fsim.1998.0160.

Balasubramanian, S., Baby Rani, P., Prakash, A. A., \& Prakash, M. (2012). Antimicrobial properties of skin mucus from four freshwater cultivable fishes (Catla catla, Hypophthalmichthys molitrix, Labeo rohita and Ctenopharyngodon idella). African Journal of Microbiology Research, 24, 5110-5120. https://doi. org/10.5897/AJMR11.532.

Bragadeeswaran, S., Priyadharshini, S., Prabhu, K., Raj, S., \& Rani, S. (2011). Antimicrobial and hemolytic activity of fish epidermal mucus Cynoglossus arel and Arius caelatus. Asian Pacific Journal of Tropical Medicine, 4, 305-309. https://doi.org/10.1016/S1995-7645(11)60091-6.

Bragadeeswaran, S., \& Thangaraj, S. (2011). Hemolyrtic and antibacterial studies on skin mucus of eel fish, Anguilla linnaues (1758). Asian Journal of Biological Sciences, 4, 272-276. https://doi.org/10.5897/AJMR11.532.

Caruso, G., Maricchiolo, G., Genovese, L., Pasquale, F., Caruso, R., Denaro, M. G., ... Lagana, P. (2014). Comparative study of antibacterial and haemolytic activities in sea bass, European eel and blackspot seabream. The Open Marine Biology Journal, 8, 10-16. https://doi.org/10.2174/1874450801408010010.

Caruso, G., Maricchiolo, G., Micale, V., Genovese, L., Caruso, R., \& Denaro, M. G. (2010). Physiological responses to starvation in the European eel (Anguilla anguilla): effects on haematological, biochemical, non-specific immune parameters and skin structures. Fish Physiology and Biochemistry, 36, 71-83. https://doi.org/10.1007/s10695-008-9290-6.

Dhotre, M. A., Bansode, P. D., \& Shembekar, V. S. (2013). Extraction, biochemical characterization and antibacterial activity of fish mucus. Indian Streams Research Journal, 12, 1-8. https://doi.org/10.9780/22307850.

Ellis, A. E. (1999). Immunity to bacteria in fish. Fish and Shellfish Immunology, 9, 291-308. https://doi.org/10.1006/fsim.1998.0192.

Ellis, A. E. (2001). Innate host defense mechanisms of fish against viruses and bacteria. Developmental and Comparative Immunology, 25, 827-839. https:// doi.org/10.1016/S0145-305X(01)00038-6.

Graham, J. B., \& Lee, H. J. (2004). Breathing air in air: in what ways might extant amphibious fish biology relate to prevailing concepts about early tetrapods, the evolution of vertebrate air breathing, and the vertebrate land transition? Physiological and Biochemical Zoology, 77, 720-731. https://doi. org/10.1086/425184.

Hellio, C., Pons, A. M., Beaupoil, C., Bourgougnon, N., \& Le Gal, Y. (2002). Antibacterial, antifungal and cytotoxic activities of extracts from fish epidermis and epidermal mucus. International Journal of Antimicrobial Agents, 20, 214-219. https://doi.org/10.1016/50924-8579(02)00172-3.

Ingram, G. A. (1980). Substances involved in the natural resistance of fish to infection-a review. Journal of Fish Biology, 16, 23-60. https://doi.org/10.1111/j. 1095-8649.1980.tb03685.x.

Lemaître, C., Orange, N., Saglio, P., Saint, N., Gagnon, J., \& Molle, G. (1996). Characterization and ion channel activities of novel antibacterial proteins from the skin mucosa of carp (Cyprinus carpio). European Journal of Biochemistry, 240, 143-149. https://doi.org/10.1111/.j.1432-1033.1996.0143h.x.

Lowry, O. H., Rosenbrogh, A. L., Farr, R. J., \& Randall, R. J. (1951). Protein measurement with the folin phenol reagent. Journal of Biological Chemistry, 193, 265-272.

Manivasagan, P., Annamalai, N., Ashokkumar, S., \& Sampathkumar, P. (2009). Studies on the proteinaceous gel secretion from the skin of the catfish, Arius maculatus (Thunberg, 1792). African Journal of Biotechnology, 8, 7125-7129.

Rakers, S., Niklasson, L., Steinhagen, D., Kruse, C., Schauber, J., Sundell, K., \& Paus, R. (2013). Antimicrobial peptides (AMPs) from fish epidermis: perspectives for investigative dermatology. Journal of Investigative Dermatology, 133, 11401149. https://doi.org/10.1038/jid.2012.503.

Rao, V., Marimuthu, K., Kupusamy, T., Rathinam, X., Arasu, M. V., Al-Dhabi, N. A., \& Arockiaraj, J. (2015). Defense properties in the epidermal mucus of different freshwater fish species. Aquaculture, Aquarium, Conservation \& LegislationInternational Journal of the Bioflux Society (AACL Bioflux), 8, 184-194.

Ravi, V., Kesavan, K., Sandhya, S., \& Rajagopal, S. (2010). Antibacterial activity of the mucus of mudskipper Boleophthalmus boddarti from Vellar Estuary. AES Bioflux, 2, 11-14.

Shephard, K. L. (1993). Mucus on the epidermis of fish and its influence on drug delivery. Advanced Drug Delivery Reviews, 11, 403-417. https://doi.org/10. 1016/0169-409X(93)90018-Y.

Shephard, K. L. (1994). Functions for fish mucus. Reviews in Fish Biology and Fisheries, 4, 401-429. https://doi.org/10.1007/BF00042888.

Subramanian, S., Mackinnon, S. L., \& Ross, N. W. (2007). A comparative study on innate immune parameters in the epidermal mucus of various fish species. Comparative Biochemistry and Physiology Part B: Biochemistry and Molecular Biology, 148, 256-263. https://doi.org/10.1016/j.cbpb.2007.06.003.

Subramanian, S., Rose, N. W., \& Mackinnon, S. L. (2008). Comparison of antimicrobial activity in the epidermal mucus extracts of fish. Comparative Biochemistry and Physiology Part B: Biochemistry and Molecular Biology, 150, 85-92. https://doi.org/10.1016/j.cbpb.2008.01.011.

Uribe, C., Folch, H., Enriquez, R., \& Moran, G. (2011). Innate and adaptive immunity in teleost fish: a review. Veterinární Medicína, 56, 486-503.

Uthayakumar, V., Ramasubramanian, V., Senthilkumar, D., Brindha, P. V., \& Harikrishnan, R. (2012). Biochemical characterization, antimicrobial and hemolytic studies on skin mucus of freshwater spiny eel Mastacembelus armatus. Asian Pacific Journal of Tropical Biomedicine, 2012, 863-869. https:// doi.org/10.1016/S2221-1691(12)60325-6.

Vennila, R., Kumar, K. R., Kanchana, S., Arumugam, M., Vijayalakshmi, S., \& Balasubramaniam, T. (2011). Preliminary investigation on antimicrobial and proteolytic property of the epidermal mucus secretion of marine stingrays. Asian Pacific Journal of Tropical Biomedicine, 1, 239-243. https://doi.org/10. 1016/S2221-1691(11)60162-7.

Wei, O. Y., Xavier, R., \& Marimuthu, K. (2010). Screening of antibacterial activity of mucus extract of snakehead fish, Channa striatus (Bloch). European Review for Medical and Pharmacological Sciences, 14, 675-681.

Yano, T. (1996). The non-specific immune system: humoral defense. In G. Iwama, \& T. Nakanishi (Eds.), The fish immune system: Organism, pathogen and environment, (pp. 105-157). London: Academic Press.

\section{Submit your manuscript to a SpringerOpen ${ }^{\circ}$ journal and benefit from:}

- Convenient online submission

- Rigorous peer review

- Open access: articles freely available online

High visibility within the field

- Retaining the copyright to your article

Submit your next manuscript at $\boldsymbol{\nabla}$ springeropen.com 